\title{
Suppression of OsVPE3 Enhances Salt Tolerance by Attenuating Vacuole Rupture during Programmed Cell Death and Affects Stomata Development in Rice
}

\author{
Wenyun Lư ${ }^{1 \dagger}$, Minjuan Deng ${ }^{2 \dagger}$, Fu Guo ${ }^{1}$, Mingqiang Wang ${ }^{1}$, Zhanghui Zeng ${ }^{1}$, Ning Han ${ }^{1}$, Yinong Yang ${ }^{1,3}$, \\ Muyuan Zhu ${ }^{1}$ and Hongwu Bian ${ }^{1 *}$
}

\begin{abstract}
Background: Vacuolar processing enzymes (VPEs) are cysteine proteinases that act as crucial mediators of programmed cell death (PCD) in plants. In rice, however, the role of VPEs in abiotic stress-induced PCD remains largely unknown. In this study, we generated OSVPE3 overexpression and suppression transgenic lines to elucidate the function of this gene in rice.

Results: Survival rate and chlorophyll retention analyses showed that suppression of OSVPE3 clearly enhanced salt stress tolerance in transgenic rice compared with wild type. Furthermore, fragmentation of genomic DNA was inhibited in plants with down-regulated OSVPE3. Vital staining studies indicated that vacuole rupture occurred prior to plasma membrane collapse during salt-induced PCD. Notably, overexpression of OsVPE3 promoted vacuole rupture, whereas suppression of OSVPE3 attenuated or delayed the disintegration of vacuolar membranes. Moreover, we found that suppression of OSVPE3 caused decreased leaf width and guard cell length in rice.

Conclusions: Taken together, these results indicated that suppression of OSVPE3 enhances salt tolerance by attenuating vacuole rupture during PCD. Therefore, we concluded that OsVPE3 plays a crucial role in vacuole-mediated PCD and in stomatal development in rice.
\end{abstract}

Keywords: OsVPE3, Programmed cell death, Rice, Salt stress, Stomata, Vacuolar processing enzyme

\section{Background}

Rice (Oryza sativa L.) is one of the most important cereal crops for more than half of the world's population. According to estimates, the world will need to produce $25 \%$ more rice by 2030 to meet the challenges of feeding increasing populations. However, the increasing soil salinization of limited farmland is becoming a serious global threat to sustained rice production (Khatun and Flowers 1995; Sahi et al. 2006; Gao et al. 2007). Therefore, enhancing salt-tolerance is a serious concern for crop breeding programs.

\footnotetext{
* Correspondence: hwbian@zju.edu.cn

${ }^{\dagger}$ Equal contributors

'Institute of Genetics and Regenerative Biology, Key Laboratory for Cell and Gene Engineering of Zhejiang Province, College of Life Sciences, Zhejiang University, Hangzhou, China

Full list of author information is available at the end of the article
}

Programmed cell death (PCD) is a highly conserved and genetically controlled process in multicellular organisms. PCD is involved in maintaining cellular homeostasis, development and senescence(Azeez et al. 2007; Williams and Dickman 2008), and this process is triggered by a variety of abiotic and biotic stresses (Huh et al. 2002; Lam 2004; Gechev et al. 2006). Plant and animal cells share many hallmarks of PCD, including cytoplasm shrinkage, chromatin condensation, DNA cleavage, mitochondrial swelling, organelle disruption and plasma membrane collapse (Mittler et al. 1997; van Doorn 2011; De Pinto et al. 2012). However, plants also exhibit unique features of PCD due to the presence of chloroplasts and vacuoles (Samuilov et al. 2003; Hatsugai et al. 2006; Kim et al. 2012; Wituszynska et al. 2015). Vacuoles are storage organelles that function as reservoirs for both hydrolytic enzymes 
and defence proteins, and vacuoles play several roles in stress response, development and pathogen defence. Recent studies have suggested that vacuole-mediated cell death is a response to various stresses in plants (Hatsugai et al. 2006; Hatsugai et al. 2015). Under salt stress, early events include the production of reactive oxygen species (ROS) and increased cytoplasmic calcium concentrations (Dionisio-Sese and Tobita 1998; Menezes-Benavente et al. 2004; Kudla et al. 2010) followed by PCD. In addition, vacuole rupture is a trigger for nuclear degradation during PCD (Obara et al. 2001). However, the genes and regulatory networks involved in vacuole-mediated cell death remain unidentified.

Vacuolar processing enzymes (VPEs) are cysteine proteinases involved in the processing of vacuolar proteins and the maturation of seed storage proteins in plants (Haranishimura et al. 1991; Hiraiwa et al. 1993; Rojo et al. 2003; Wang et al. 2009). VPEs are expressed in senescent tissues, and their expression patterns have been linked to PCD (Hara-Nishimura et al. 1998; Kinoshita et al. 1999). For example, it has been shown that VPEs regulate systematic cell death induced by viral, aluminium and heat stress, which is mediated by caspase-1-like activity during PCD (Hatsugai et al. 2004b; Li et al. 2012; Kariya et al. 2013). VPEs and caspase-1 share conserved structural properties, particularly the Asp pocket of caspase-1, which includes three crucial amino acids (Arg-179, Arg-341 and Ser-347) (Hatsugai et al. 2006). Although VPEs and caspase-1 share many similarities, the subcellular localizations of these two proteases are completely different. Namely, VPEs localize to vacuoles, whereas animal caspases localize to the cytosol. As initiators of plant PCD, VPEs trigger cell death through vacuolar collapse (Hatsugai et al. 2004a). To date, several types of VPEs have been reported to be involved in PCD as follows: NbVPE1a and NbVPE1b in Nicotiana; and AtyVPE in Arabidopsis. In rice, however, the role of VPEs in the vacuole-mediated cell death remains unknown.

The rice genome contains four VPE homologous genes as follows: OsVPE1 (Os04g45470), OsVPE2 (Os01g37910), OsVPE3 (Os02g43010) and OsVPE4 (Os05g51570) (Deng et al. 2011). Phylogenetically, OSVPE1 and OsVPE3 are more similar to Arabidopsis At $\beta V P E$, whereas OsVPE2 and OsVPE4 are more similar to AtaVPE and AtyVPE. OsVPE1, a homolog of $A t \beta V P E$, plays a crucial role in the maturation of glutelins in seeds (Wang et al. 2009). Previous work by our group has shown that the transcription of OsVPE2 and OsVPE3, but not of OsVPE1 and OsVPE4, can significantly enhance salt-induced PCD (Deng et al. 2011; Kim et al. 2014). In this study, we aimed to elucidate the role of OsVPE3 in the context of salt stress. To determine the function of OsVPE3 in rice under salt stress, we generated transgenic lines to either overexpress and suppress OsVPE3, and we found that OsVPE3 regulates the collapse of vacuolar membranes during PCD. In addition, we found that OsVPE3 plays a role in leaf and stomata development in rice.

\section{Results}

\section{Expression pattern and localization of OsVPE3}

A comparison between genomic DNA and cDNA revealed thatOsVPE3 (Os02g43010) contains nine exons and eight introns (Fig. 1a), and OSVPE3 encodes a peptide of 496 amino acids. The red letters in Fig. 1 indicate essential amino acids in the catalytic site and substrate pocket that mediate caspase-like activity (Fig. 1b) (Nicholson 1999; Hara-Nishimura et al. 2005; Hatsugai et al. 2015).

To determine the subcellular localization of OSVPE3, the full-length cDNA was fused to green fluorescent protein (GFP) under control of the $35 \mathrm{~S}$ promoter. An OsVPE1-GFP fusion gene driven by the $35 \mathrm{~S}$ promoter was used as a control. OsVPE1, a seed-type vacuolar processing enzyme, has been shown to localize to vacuoles in onion cells (Wang et al. 2009). These constructs were transiently transformed into rice protoplasts. We searched for GFP signals in vacuoles for the 35S:OsVPE1-GFP and 35S:OsVPE3-GFP fusion constructs, and no GFP signal was observed in vacuoles for the 35S: GFP construct (Fig. 1c). It was reported that GFP was unstable in the acidic vacuoles of plants under the light condition, because light would cause the rapid degradation of $27-\mathrm{kDa}$ GFP by pre-existing proteinase in vacuoles at $\mathrm{pH} 5.5$ (Tamura et al., 2003). In protoplast transient assay, isolated protoplasts were kept in the dark condition to protect from light damage, thus the GFP fluorescence can be observed in the vacuoles..Consequently, this result suggested that OsVPE3 is a vacuole-targeting protein similar to OsVPE1.

To investigate the expression pattern of OsVPE3 in rice, transcription levels were examined in various tissues by quantitative RT-PCR. Expression analysis revealed that OsVPE3 is expressed in tissues of the leaf, root, booting panicle and immature embryo (Fig. 1d). OsVPE3 expression increased rapidly in the leaves of 10-day-old seedlings compared with 5-day-old seedlings. The highest transcriptional expression level of OsVPE3 was detected in immature embryos. These results demonstrated that OsVPE3 is actively transcribed in the leaves and developing embryos of rice.

\section{Generation of Transgenic Rice Lines}

In our previous work, we found that the expression of OsVPE3 is dramatically induced by salt stress (Deng et al. 2011; Kim et al. 2014). However, the role of the OsVPE3 gene in rice remains largely unknown. To investigate if OsVPE3 is involved in the process of $\mathrm{PCD}$, OsVPE3 was overexpressed and suppressed using transgenic lines (Fig. 2a, b). Homozygous T3 transgenic seeds 


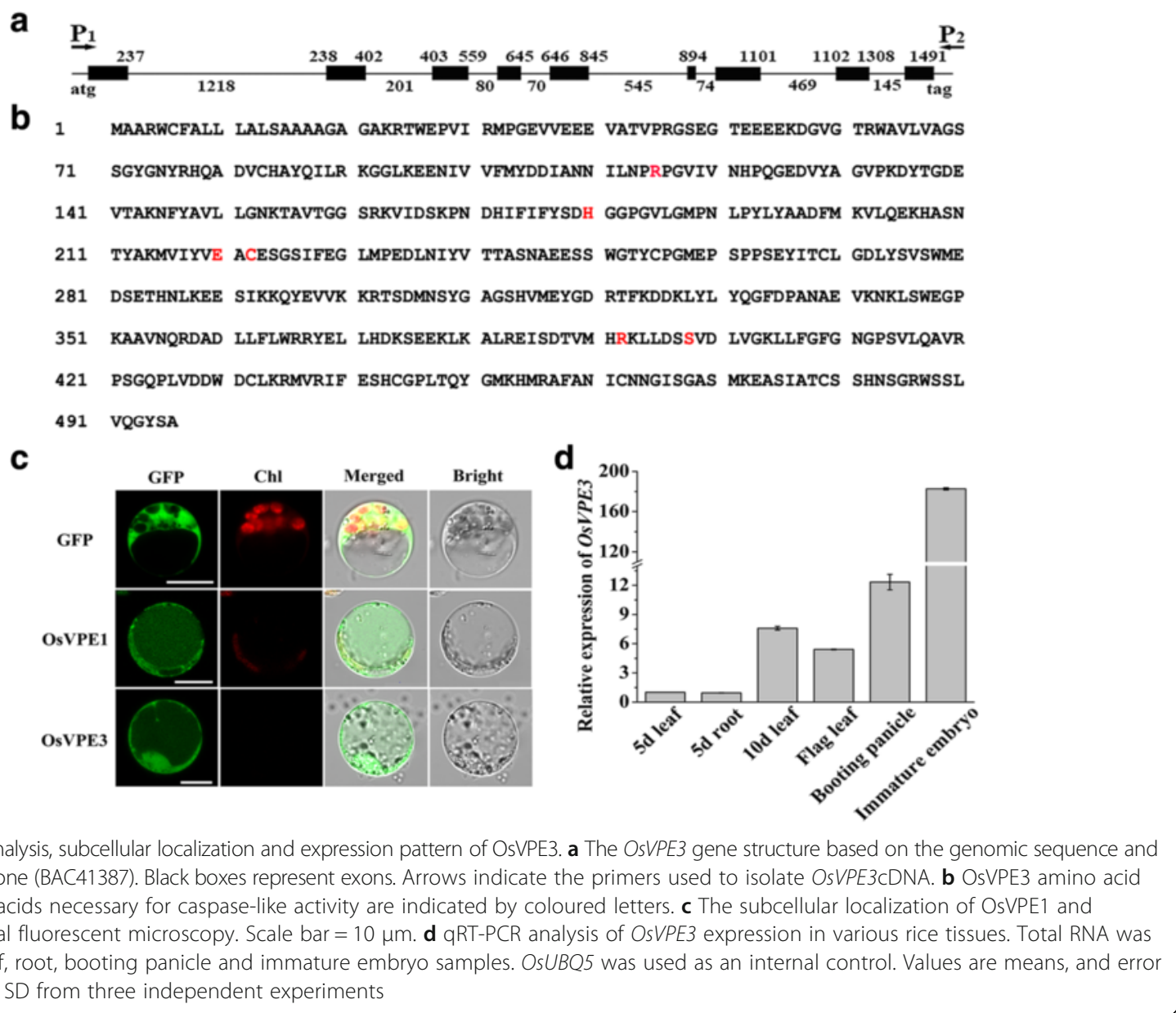

were used for further investigation. Quantitative RT-PCR analysis confirmed that the expression levels of OsVPE3 were strongly increased in the overexpression lines (OE-1 and OE-2) and decreased significantly in the RNA interference transgenic lines (RNAi-1) compared with WT (Fig. 2c).

Previous studies showed that OsVPE1 plays a crucial role in the maturation of glutelins in seeds (Wang et al. 2009). To examine the role of OsVPE3 on seed proteins, we performed SDS-PAGE analysis to compare the proteins in WT and transgenic lines. Our data showed that the major storage proteins yielded three bands of approximately 20, 40 and $57 \mathrm{kDa}$ in rice (Fig. 2d). The 57$\mathrm{kDa}$ protein is a glutelin precursor (Yamagata et al. 1982; Krishnan and Okita 1986). Compared with WT, $57 \mathrm{kDa}$ protein levels was increased to 1.33 fold in the OsVPE3-RNAi line, whereas reduced to approximately 0.80-0.84 in the overexpression lines.(Fig. 2d). Accordingly, the grain width and 1000-grian weight of the RNAi line decreased significantly compared with WT and overexpression lines (Additional file 1: Figure S1). These results indicated that OsVPE3 is involved in the processing of seed storage proteins in rice.

\section{Suppression of OsVPE3 Enhances Salt Stress Tolerance in Rice}

Based on our previous studies, we hypothesized that OsVPE3 might act as a trigger in salt-induced PCD. To determine if OsVPE3 is involved in salt stress tolerance in rice, 4-week-old WT and transgenic plants were treated with $150 \mathrm{mM} \mathrm{NaCl}$ for 3 days. Before $\mathrm{NaCl}$ treatment, the expression levels of OsVPE3 were measured in the fourth leaf of each line, confirming that the transcript levels of OsVPE3 were increased in overexpression lines (OE-1 and OE-2) and significantly suppressed in the RNAi transgenic lines (Fig. 3a, b). Under salt stress, chlorosis is a common symptom in rice leaves. Chlorophyll contents were measured after 3 days of $\mathrm{NaCl}$ treatment, and then survival rates were calculated after 7 days of recovery culture under normal growth conditions. When the plants were exposed to $150 \mathrm{mM} \mathrm{NaCl}$ for 3 days, the leaves of WT and overexpression lines turned yellow. In contrast, the chlorosis phenotype was significantly weakened in the RNAi line (Fig. 3c, d). Approximately $56.1 \pm 15.0 \%$ of RNAi plants remained alive after recovery culture, whereas the survival rates of WT and overexpression transgenic lines (OE-1, OE-2) were significantly lower than that of RNAi line 


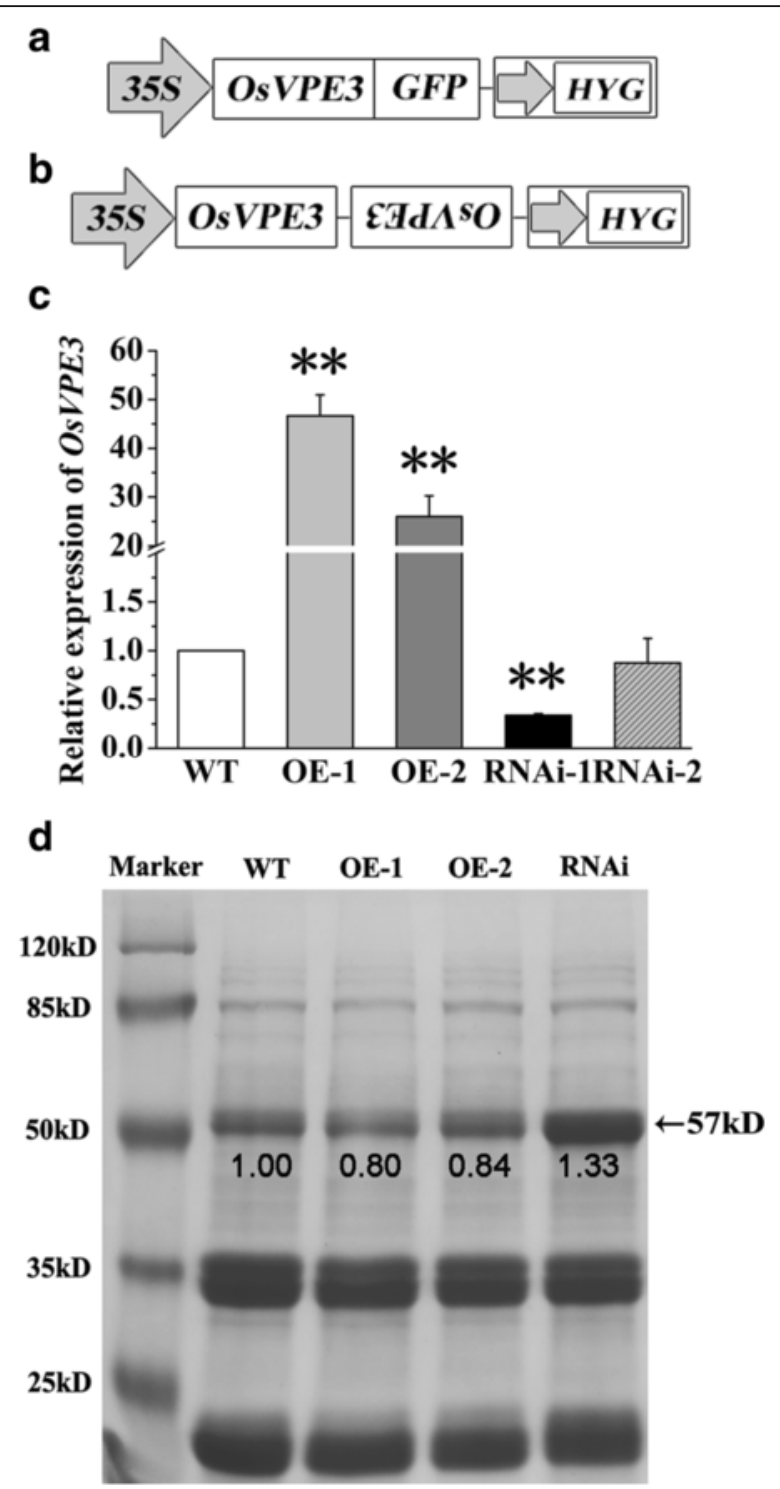

Fig. 2 Generation and analysis of transgenic lines. A diagram of the vector constructs used to generate the overexpression lines (a) and RNAi line (b). c Expression levels of OSVPE3 in WT and transgenic lines were determined by qRT-PCR. OsUBQ5 was used as an internal control. Values are means, and error bars represent the SD $(n>1)$ from three independent experiments. Asterisks indicate a significant difference between WT and transgenic lines (t-test; ${ }^{* *}, P<0.01$ ). d SDS-PAGE analysis of seed storage proteins in WT and transgenic lines. The intensity of protein bands was measured by Image J software. Arrow indicates the 57-kDa glutelin precursor

(Fig. 3a, e). Remarkably, the RNAi line had a significantly higher chlorophyll content and relative survival rate compared with the WT and overexpression lines (Fig. 3d, e). These results demonstrated that suppression of OsVPE3 inhibits the development of chlorosis and improves salt tolerance in rice.

\section{Suppression of OsVPE3 Inhibits the Formation of Dna} Ladders in Salt-Induced PCD

To further investigate the effect of OsVPE3 on rice tolerance to salt stress, 3-day-old WT and transgenic seedlings were treated with high concentration $\mathrm{NaCl}(100 \mathrm{mM}$, $150 \mathrm{mM}$ ) for 3 days. The results showed that RNAi seedlings had the highest root relative elongation rate and overexpression seedlings were the most sensitive to salt stress (Fig. 4a). At the same time, Evans Blue staining confirmed that the root tips of the RNAi line maintained highest cell viability after exposure to $150 \mathrm{mM} \mathrm{NaCl}$ for 3 days compared to other lines (Fig. 4b). The fragmentation of genomic DNA is a typical biochemical and morphological feature of PCD. To determine if the suppression of OsVPE3 can inhibit salt-induced PCD, DNA fragmentation was measured in transgenic lines and WT plants treated with $300 \mathrm{mM} \mathrm{NaCl}$ for $8 \mathrm{~h}$. As shown in Fig. 4c, clear and visible DNA laddering was observed in the OsVPE3-overexpression lines, whereas DNA laddering was significantly inhibited in the RNAi line. This result suggested that suppression of OsVPE3 inhibits the formation of DNA ladders during saltinduced PCD.

Because OsVPE3 has high homology with OsVPE1, we performed qRT-PCR experiment to detect the expression levels of OsVPE homologous genes in the roots of transgenic lines (Fig. 4d). The results showed that the expression level of OsVPE3 was decreased dramatically in RNAi line; meanwhile, OsVPE1 expression was also reduced compared with the WT. The expression level of OsVPE3 was much more decreased than OsVPE1 in the RNAi line. Our previous work has shown that the transcription of OsVPE2 and OsVPE3, but not of OsVPE1 and OsVPE4, can significantly increase in the salt-induced PCD (Deng et al. 2011; Kim et al. 2014), suggesting that the transcription of OsVPE1 was not responsive to salt stress in rice roots (Deng et al. 2011). Therefore, we conclude that OsVPE3 plays a crucial role in salt stressmediated PCD.

\section{Suppression of OsVPE3 Helps Maintain the Integrity of Vacuolar Membranes During Salt-Induced Pcd}

Unlike in animal cells, the vacuole is a unique organelle used to store a variety of hydrolytic enzymes and defence proteins in plant cells (Neuhaus et al. 1991; Yamada et al. 2001). The rupture of vacuolar membranes releases these components and leads to cell death (Mino et al. 2006). To elucidate the role of OsVPE3 in the integrity of vacuolar membranes during $\mathrm{PCD}$, rice protoplasts were stained with Trypan Blue and the BCECF-AM fluorescent probe. Trypan Blue staining is a reporter of cell death based on disintegrated cellular membranes, and BCECF-AM labels the vacuole lumen as green fluorescence to reveal intact vacuoles (Swanson and Jones 1996). BCECF-staining 

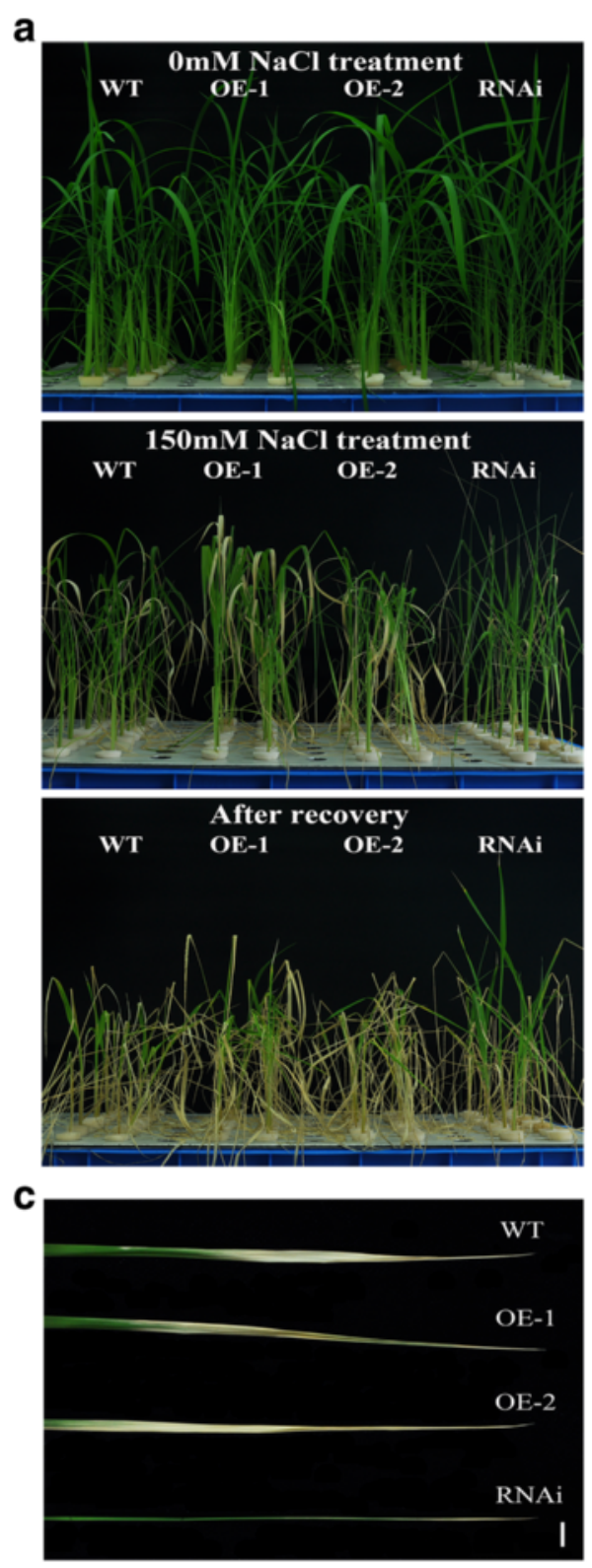

e

Fig. 3 Suppression of OSVPE3 improved survival rate and inhibited chlorosis under salt stress. a Plants were grown for 4 weeks, treated with 150 $\mathrm{mMNaCl}$ for 3 days and then allowed to recover for 7 days. $\mathbf{b}$ Expression levels of OSVPE3 in WT and transgenic lines as determined by qRT-PCR. Total RNA was extracted from the fourth leaves. OsUBQ5 was used as an internal control. Values are means, and error bars represent the SD from three independent experiments. Asterisks indicate a significant difference between WT and transgenic lines (t-test; ${ }^{* *}, P<0.01$ ). c The fourth leaves of $\mathrm{NaCl}$-treated plants. Bar $=1 \mathrm{~cm}$. $\mathbf{d}$ Chlorophyll retention in the fourth leaves of $\mathrm{NaCl}$-treated plants prior to recovery. Values are means, and error bars represent the SD from three independent experiments. Asterisks indicate a significant difference between WT and transgenic lines (t-test; $\left.{ }^{*}, P<0.05\right)$. e Survival rates of $\mathrm{NaCl}$-treated plants 7 days after recovery. Values are means, and error bars represent the SD $(n>20)$ of three independent experiments. Asterisks indicate a significant difference between WT and transgenic lines (t-test; ${ }^{*}, P<0.05$ )

revealed that protoplasts prior to $\mathrm{NaCl}$ treatment accumulated strong fluorescence signal in vacuoles in both WT and transgenic lines (Fig. 5a, the first horizontal low). Protoplasts subjected to $100 \mathrm{mM} \mathrm{NaCl}$ treatment for $3 \mathrm{~h}$ can be sorted into three types as follows (Fig. 5a, b): Type 1, BCECF-positive and Trypan Blue-negative, indicating living cells with intact cellular membranes

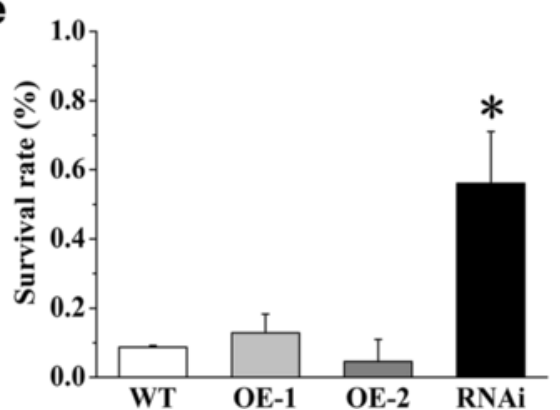

b
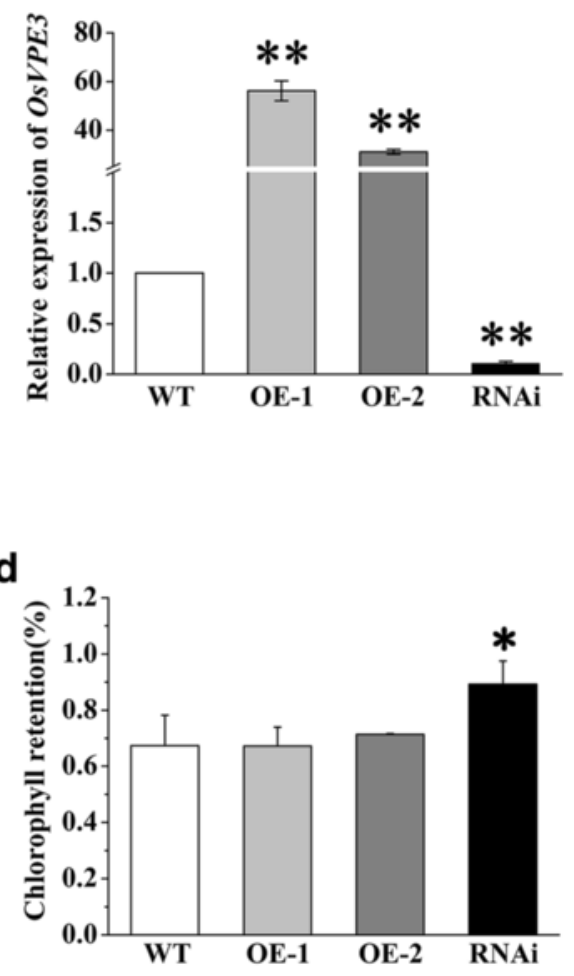

and vacuoles; Type 2, BCECF-negative and Trypan Blue-negative, indicating living cells with disintegrated vacuolar membranes (as shown by distribution of BCECF fluorescence signal outside of the vacuoles); and Type 3, BCECF-negative and Trypan Blue-positive, indicating dead cells with collapsed vacuoles (as shown by no BCECF fluorescence signal). After $100 \mathrm{mM} \mathrm{NaCl}$ treatment, the 
a

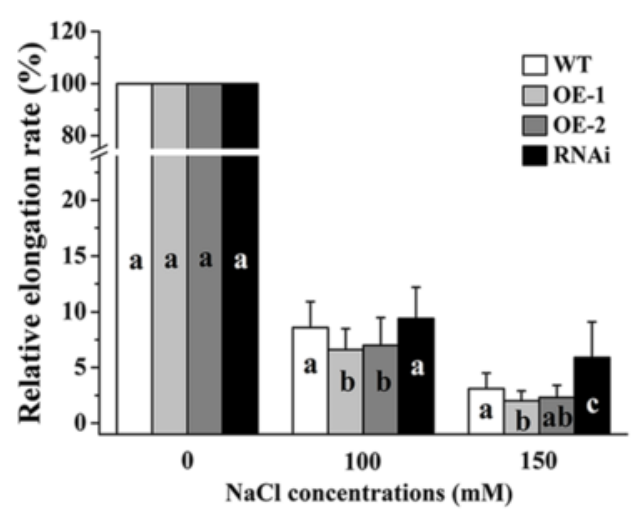

d

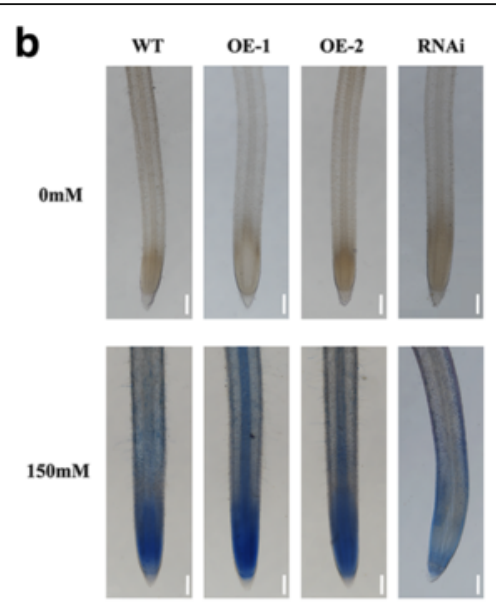

C

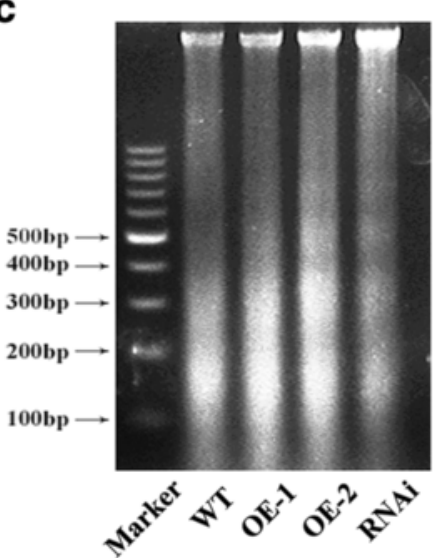

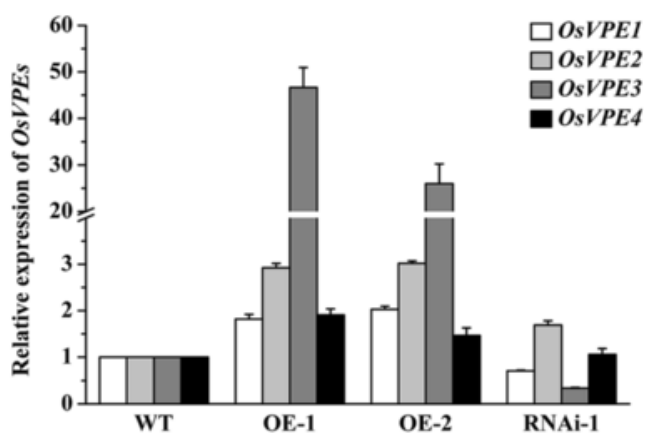

Fig. 4 Inhibition of the primary root growth and DNA ladder formation in WT and transgenic lines under salt stress. a Three-day-old seedlings were treated with 0,100 and $150 \mathrm{mM} \mathrm{NaCl}$ for 5 days. The root relative elongation rates were calculated as described in the Materials and methods. Values are means, and error bars represent the SD of three independent experiments $n>30$ ) and the different letters denote the significant difference among different lines (ANOVA, $P<0.05$ ). b Primary root cell viability was presented using Evans Blue dye in WT and transgenic lines treated with 0 or $150 \mathrm{mMNaCl}$ for 3 days. Bars $=200 \mu \mathrm{m}$. c DNA ladder formation after treatment with $300 \mathrm{mMNaCl}$ for $8 \mathrm{~h}$ in root tips. $\mathbf{d}$ Relative expression levels of OsVPE homology genes determined by qRT-PCR. Total RNA was extracted from the roots. OsUBQ5 was used as an internal control. Values are means, and error bars represent the SD from three independent experiments

survival protoplasts (type 1) decreased to $54.6 \pm 2.4$ and $52.7 \pm 2.4 \%$ of the levels in the WT and OE- 1 lines, respectively. In contrast, the survival rate of protoplasts (Type 1) from the RNAi line was $70.3 \pm 6.5 \%$, which was significantly higher than that of the WT and OE-1 lines. The results showing that many of the protoplasts (Type 2) with degraded vacuolar membranes were alive suggested that cell death was preceded by vacuolar collapse. Only $8.4 \pm 4.1 \%$ of the RNAi cells belonged to Type 2 , which involved vacuole rupture before cell death. Interestingly, $37.5 \pm 3.1 \%$ of OsVPE3-overexpressing cells belonged to Type 3, which was significantly higher than in the WT and RNAi lines. Notably, certain Type 3 protoplasts from the RNAi line still showed weak fluorescence in the vacuolar region, thereby suggesting that OsVPE3-RNAi attenuated or delayed the disintegration of vacuolar membranes even after cell death. Taken together, these results demonstrated that suppression of OsVPE3 prevents vacuole rupture during salt-induced PCD (Fig. 5a).

\section{Suppression of OsVPE3 Results in Decreased Leaf Width and Stomatal Size}

Compared with WT, there were no obviously morphological changes in the transgenic plants at the early seedling stage. However, after four weeks of growth, the RNAi transgenic line exhibited narrower leaves than WT (Fig. 6a). Blade width of the fourth leaf was approximately $6.00 \pm 0.54 \mathrm{~cm}$ in the WT plants, whereas the blade width was approximately $5.50 \pm 0.33 \mathrm{~cm}$ in the RNAi line (Fig. 6b). Further observation revealed stomata size in the RNAi line was smaller than in WT plants (Fig. 6c). Statistical analysis showed that only $25 \%$ of guard cells were longer than $20 \mu \mathrm{m}$ in the RNAi line whereas $64 \%$ in the WT plants. The majority of guard cells were between 15 


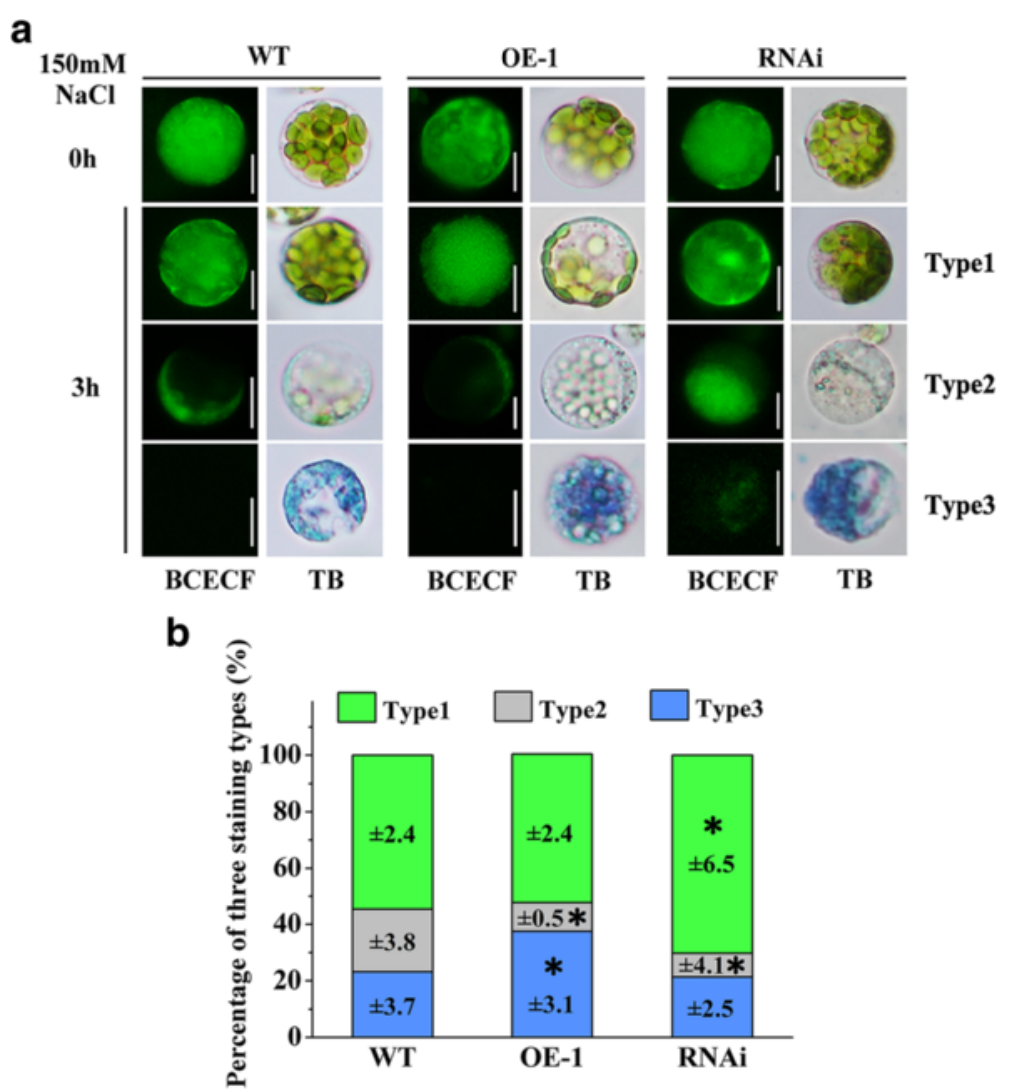

Fig. 5 Suppression of OSVPE3 alleviates vacuole rupture under salt stress. a Protoplasts from WT and transgenic lines were stained with the BCECF-AM vital dye (final concentration $=10 \mu \mathrm{M}$ ) for $2 \mathrm{~h}$ and then treated with $100 \mathrm{mM} \mathrm{NaCl}$ for $3 \mathrm{~h}$. Before the BCECF fluorescent images were inspected, the protoplasts were stained with Trypan Blue (TB). Type 1 protoplasts were living cells with intact vacuoles. Type 2 protoplasts were living cells with disintegrated vacuolar membranes. Type 3 protoplasts were dead. $\mathbf{b}$ Statistical analysis of three types of protoplasts after treatment with $100 \mathrm{mM} \mathrm{NaCl}$. Data represent the means \pm SD $(n>100)$ for three independent replicates. Asterisks indicate a significant difference between the WT and transgenic lines (t-test; $\left.{ }^{*}, P<0.05\right)$

and $20 \mu \mathrm{m}$ in the RNAi line (Fig. 6d). There were no significant differences in leaf width and guard cell length between the OE-1 line and WT plants. The expression pattern of OsVPE3 showed that OsVPE3 is actively transcribed in the leaves and developing embryos of rice (Fig. 1d). We speculated that the expression levels of OsVPE3 were abundant enough for the leaf development in WT, thus the OsVPE3-overexpression lines exhibited weak phenotype compared with the WT.

In addition, we tested the percentage of water loss of detached leaves from WT and transgenic lines. The data indicated that the percentage of water loss of RNAi leaves was significantly lower than other lines (Additional file 1: Fig. S2), suggesting suppression of OsVPE3 enhanced the dehydration tolerance. The above results demonstrated that suppression of OsVPE3 caused decreased leaf width and guard cell length, promoting a dehydration tolerance in rice leaves.

Furthermore, we analysed the expression of genes related to stomatal development by qRT-PCR. According to known reports, there are five critical genes related to the development of stomata in rice, namely OsTMM (TOO MANY MOUTHS), OsSPCH1 (SPEECHLESS), OsSPCH2, OsMUTE and OsFAMA (Liu et al. 2009). $O S T M M$ is a receptor for extracellular ligand, characterized as a set of key regulators in stomatal production and patterning (Balcerowicz and Hoecker 2014). OsSPCH1, OsSPCH2, OsMUTE and OsFAMA are essential transcription factors in the stomata patterning and development (Liu et al. 2009). We monitored the expressions of these genes (the data of OsFAMA is not shown because of its low expression level in rice leaves). As shown in Fig. 7, the expression levels of OSTMM, OSSPCH1 and OsMUTE were significantly down-regulated in the RNAi line compared with WT. Consistently, these three genes showed upregulated tendencies in overexpression lines, while only the expression of $\mathrm{OsSPCH} 2$ decreased significantly. It revealed that OsVPE3 might mainly affect the level expression of OsTMM, OsSPCH1 and OsMUTE in stomata developmental pathway to change the guard cell size. 

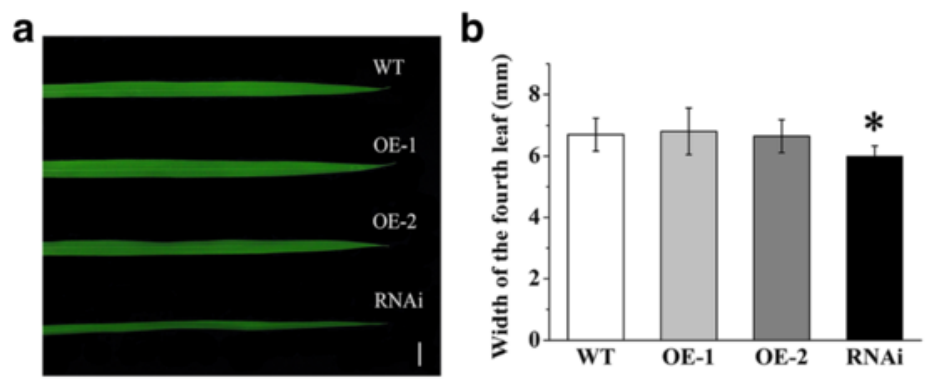

C

d
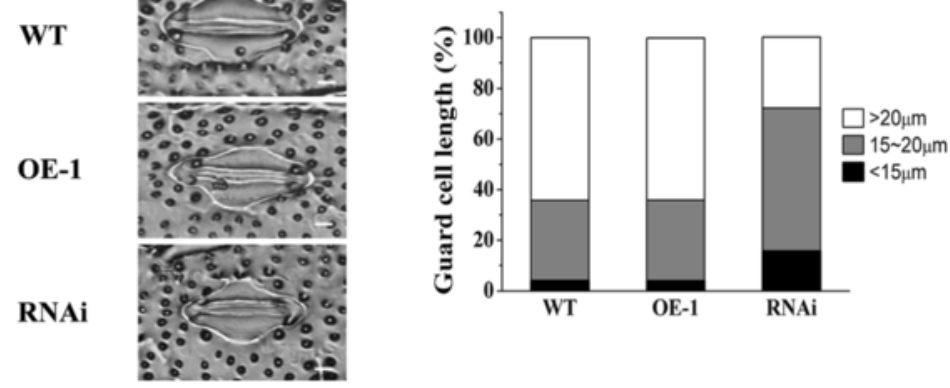

Fig. 6 Fourth leaf width and guard cell size in WT and transgenic lines. a Images of fourth leaves of WT and transgenic lines. Bars $=1 \mathrm{~cm}$. b Measurements of the maximum fourth leaf width in WT and transgenic lines. Values indicate the mean, and error bars represent the SD $(n>10)$. An asterisk indicates a significant difference between the WT and transgenic lines (t-test; $P<0.05)$. c Images of stomata in WT and transgenic lines. Bars $=5 \mu \mathrm{m}$. d Percentage of stomata with various guard cell lengths in WT and transgenic lines $(n>500)$
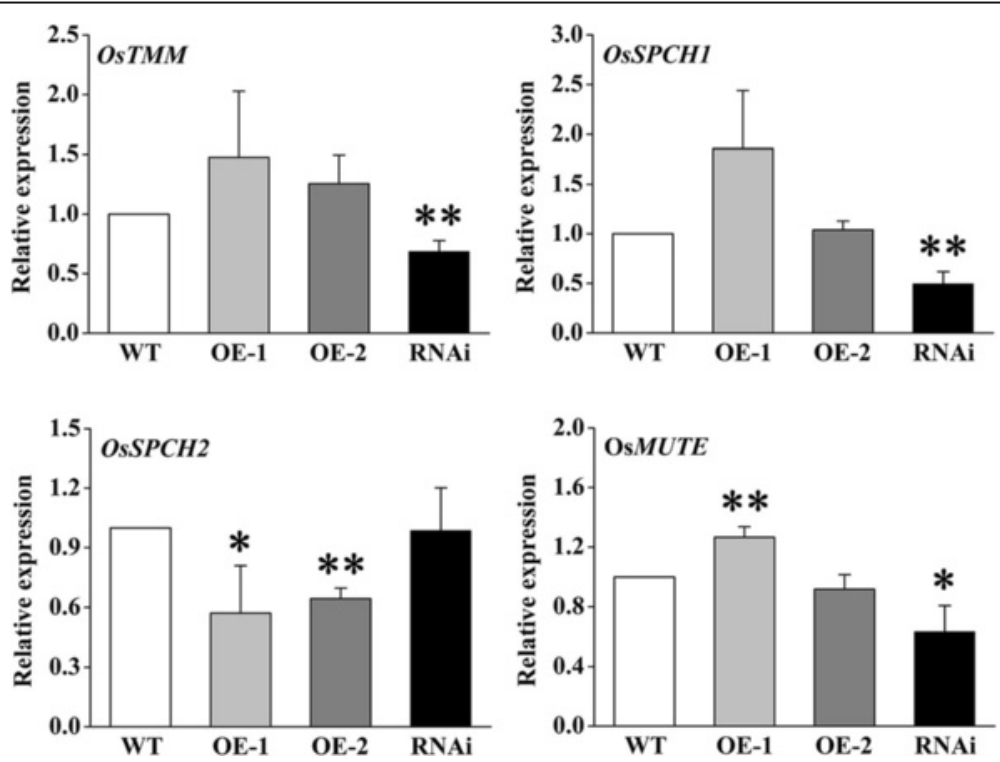

Fig. 7 Effect of OSVPE3 on the expression levels of genes related to stomatal development. Expression levels of OsTMM, OSSPCH1, OsSPCH2, and OSMUTE in WT and transgenic lines as determined by qRT-PCR. Total RNA was extracted from the shoots of 5-day-old plants. OsUBQ5 was used as an internal control. Values are means, and error bars represent the SD from three independent experiments. Asterisks indicate a significant difference between WT and transgenic lines (t-test; $\left.{ }^{* *}, P<0.01\right)$ 


\section{Discussion}

The main purpose of this study was to understand the role of OsVPE3 in vacuole-mediated PCD following salt stress in rice. OsVPE3 overexpression and suppression transgenic lines were created to elucidate the function of OsVPE3 in rice. Our results demonstrated that OsVPE3 plays a crucial role in the salt stress response by regulating the collapse of vacuolar membranes during PCD. In addition, OsVPE3 affected leaf and stomata guard cell development in rice.

High salinity is one of the most important abiotic stresses during crop breeding. High salinity activates the salt-overly-sensitive (SOS) system in plants, which leads to sodium exclusion from the cytosol (Zhu 2003). Under high salt conditions, excess $\mathrm{Na}^{+}$accumulates in the plant, thus increasing influx of $\mathrm{Na}^{+}$and efflux of $\mathrm{K}^{+}$(Serrano and Rodriguez-Navarro 2001; Horie et al. 2012). It has been proposed that these changes can decrease the cytosolic $\mathrm{K} / \mathrm{Na}$ ratio, thus elevating concentrations of the intracellular second messenger $\mathrm{Ca}^{2+}$ (Kudla et al. 2010) and causing ROS bursts (Zhu 2001). As a consequence of increased $\mathrm{K} / \mathrm{Na}$ ratios and salinity-induced ROS, programmed cell death would be finally triggered (Huh et al. 2002; Lin et al. 2006; Shabala 2009). A recent study in rice by our group revealed that overexpression of BCL-2, an anti-apoptotic protein, significantly reduces $\mathrm{NaCl}$-induced $\mathrm{K}+$ efflux and represses the expression of VPEs, thereby alleviating PCD symptoms(Deng et al. 2011; Kim et al. 2014).

Salt-induced PCD in plants and animals shares many consequences, including DNA fragmentation, nuclear condensation, nuclear deformation, mitochondrial involvement and endonuclease activity (Li et al. 2007; Jiang et al. 2008). Analysis of DNA laddering indicated that PCD occurs in rice seedlings under salt treatment (Fig. 4c). Compared with WT, overexpression of OsVPE3 strongly enhanced genomic DNA fragmentation, whereas OsVPE3 interference strongly repressed DNA fragmentation during PCD. This finding suggested that OsVPE3 likely plays a crucial role in the salt-induced PCD in rice.

The VPE family was originally identified as a group of processing enzymes responsible for the maturation of seed storage proteins in protein storage vacuoles (Haranishimura et al. 1991; Haranishimura et al. 1993). It was originally reported that NtVPEs have caspase- 1 activity and are essential for the virus-induced hypersensitive response involving $\mathrm{PCD}$, which led to the proposition of a new cell death mechanism mediated by VPE and cellular vacuoles (Hatsugai et al. 2004b). Subsequently, a similar function was proposed for AtyVPE in mycotoxin-induced cell death (Kuroyanagi et al. 2005). Recently, further studies have shown that VPEs are also involved in cell death under abiotic stresses (Zhang et al. 2013b). For example, AtyVPE, which is mediated by MPK6, affects heat-shock- induced PCD in Arabidopsis (Li et al. 2012). Our study found that OsVPE3 regulated salt-induced PCD in rice.

Vacuoles are essential organelles in plants, which have multiple functions including storage of a wide variety of ions, proteins and other metabolites, and maintain cytosolic ion homeostasis (Boller and Wiemken 1986; Rea and Sanders 1987). Plant vacuoles also play critical roles in stress responses, development and pathogen defence. There have been many reports concerning the relationship between vacuoles and cell death (Hara-Nishimura and Hatsugai 2011; Higaki et al. 2011). Vacuole rupture triggers nuclear degradation during PCD (Obara et al. 2001). The discovery of VPE functions in vacuoles could further explain the molecular mechanism of vacuole-mediated PCD. Similar to characterized OsVPE1, OsVPE3 localized to vacuoles (Fig. 1c). We found that vacuole integrity was impaired prior to cell death under salt treatment in WT plants. However, suppression of OsVPE3 markedly enhanced the maintenance of vacuolar membranes even in the context of cell death. In contrast, overexpression of OsVPE3 accelerated the rupture of vacuole membranes (Fig. 5). Our results strongly supported the hypothesis that OsVPE3 plays a crucial role in vacuole rupture during PCD. To date, the mechanism of VPE-mediated vacuole rupture remains unclear, due to a lack of evidence that the VPEs interact other vacuolar proteins. Based on the characteristics of VPEs, we propose that VPEs expression is upregulated by disturbances in ion homeostasis in response to abiotic stresses and that VPE precursors are self-activated to process vacuolar hydrolases and proteases, leading to vacuole rupture and cell death.

In addition to vacuole rupture, there is another interesting finding concerning the role of OSVPE3 in the development of stomata in rice. The stoma is known to be an important structure for controlling gaseous exchange and water release by transpiration (Assmann 1993), and function under stress conditions (Zhang et al. 2013a). At the same time, stomata movement may be affected by VPEs in Arabidopsis (Albertini et al. 2014). We found that leaves in the RNAi line were more curled than in wild type and that this phenomenon was more apparent under salt stress (Fig. 3). Further research showed that stomata size in the RNAi line was smaller than in WT plants (Fig. 6c, d). Small stomata may alter transpiration to improve resistance in plants. Transcriptome analysis has revealed strong expression of AtyVPE in Arabidopsis guard cells (Albertini et al. 2014). qRT-PCR analysis has confirmed that $\gamma V P E$ expression in guard cells is higher than in whole leaves, thus suggesting that this gene plays a critical role in guard cells (Albertini et al. 2014). Moreover, Arabidopsis YVPE knockout mutants reduced stomata opening and increased resistance to desiccation (Albertini et al. 2014). Our data showed that suppression of OsVPE3 down-regulated the expression levels of 
OsTMM, OsSPCH1 and OsMUTE in the stomata developmental pathway, leading to affect guard cell size in the OsVPE3-RNAi line. This finding suggests that OsVPE3 might play a role in stomata development in rice.

\section{Conclusions}

Our results demonstrated that OsVPE3 plays a crucial role in the salt stress-induced PCD by regulating the collapse of vacuolar membranes. In addition, OSVPE3 affected leaf and stomata guard cell development in rice. These findings are relevant for enhancing salt-tolerance via genetic engineering in crop breeding programs.

\section{Methods \\ Growth Conditions}

Seeds were surface sterilized with $10 \%$ sodium hypochlorite (v/v) for $30 \mathrm{~min}$, rinsed 5 times in deionized water and soaked in deionized water at $30{ }^{\circ} \mathrm{C}$ for 2 days in the dark. After germination, the seeds were transferred to a nutrient solution culture (Yoshida et al. 1976) at $\mathrm{pH}$ 5.0-6.0 in a greenhouse at $28{ }^{\circ} \mathrm{C}$ under a $16: 8 \mathrm{~h}$ light: dark cycle. The 3-day-old seedlings were treated with $300 \mathrm{mM} \mathrm{NaCl}$ for DNA ladder detection. For the expression pattern analyses, tissues were collected at different stages following seedling growth under these conditions. After 4 weeks of growth, the plants were treated with various concentrations of $\mathrm{NaCl}$.

\section{Constructs and Plant transformation}

All wild-type and mutant transgenic lines were generated in the Oryza sativa L. ssp. japonica cv. Nipponbare rice background.

For the overexpression constructs, the cDNA sequence of OsVPE3 (approximately $1488 \mathrm{bp}$ ) was amplified from the cDNA library of Nipponbare using gene-specific primer pairs. The fragments were then cloned into the pENTRD-TOPO vector (Invitrogen, Carlsbad, CA, USA) and then into the destination vector (pH7FWG2.0) by LR clonase reactions.

For the RNA interference (RNAi) constructs, a 745-bp fragment was amplified from OsVPE3, inserted into the pENTRD-TOPO vector (Invitrogen) and then cloned into pH7GWIWG2 (I) by LR clonase reactions.

Rice transformation was performed using the Agrobacterium tumefaciens-mediated co-cultivation method. Transformed calli were selected on hygromycin medium. T0 plants were self-pollinated over two generations to obtain homozygous T2 transgenic seeds. Homozygous T3 seeds were used in this study.

Primers used in this work are listed in Additional file 1: Table S1. The gene constructs used for rice transformation were verified by sequencing.

\section{Total RNA extraction and qRT-PCR Assay For Osvpe3} Expression

Total RNA was isolated using the TRIzol RNA extraction kit (Invitrogen), and first-strand cDNA was synthesized using the ReverTra Ace qPCR RT Master Mix with gDNA Remover for qRT-PCR (TOYOBO). Quantitative RT-PCR was performed using the Master cycler ep realplex system (Eppendorf, Hamburg, Germany) and the SYBR PrimeScript RT-PCR kit (Perfect Real Time; TaKaRa). OsUBQ5 was amplified as a control for the template. All primers used in this work are listed in Additional file 1: Table S1.

Protein extraction from rice grains and SDS-PAGE assays Mature seeds harvested from T3 homozygous plants were used for protein extraction. The protein extraction was performed on the described methods (Takemoto et al. 2002), and the proteins were analysed by SDS-PAGE. The density of the protein bands was measured by using the Image J software.

\section{Subcellular Localization}

The OsVPE1:GFP and OsVPE3:GFP fusions were created using Gateway cloning (Invitrogen). The full-length cDNAs of OsVPE1 and OsVPE3 (lacking stop codons) were amplified and inserted into the pENTR/D-TOPO vector (Invitrogen), and they were subsequently cloned into pUGW5 using LR clonase reactions. The fusion constructs were transformed into rice protoplasts using PEG-mediated transfection according to our previous study (Bai et al. 2014). Following transformation, rice protoplasts were incubated at $25 \pm 2{ }^{\circ} \mathrm{C}$ in the dark for 12-16 h prior to observation with a Zeiss LSM710 NLO two-photon microscopy (Germany).

\section{Chlorophyll Content Assay}

Four-week-old plants were treated with $150 \mathrm{mM} \mathrm{NaCl}$ for 3 days prior to measuring chlorophyll content. Chlorophyll was extracted from the tip of the fourth leaf. Briefly, each sample $(0.1 \mathrm{~g})$ was placed into a $10-\mathrm{mL}$ tube containing $4 \mathrm{~mL}$ of extraction solution (1: 1 ethanol: acetone) and incubated in the dark for $24 \mathrm{~h}$ at $25^{\circ} \mathrm{C}$. Absorbance of the extracts at 663 and $645 \mathrm{~nm}$ was measured using a Spekol spectrocolorimeter (Carl Zeiss GmbH, Jena, Germany). Total chlorophyll content was calculated using the following formulas (Yu et al. 2006):

$$
\begin{aligned}
& {[\mathrm{Chl} \mathrm{a}]=12.7 \times \mathrm{A} 663-2.69 \times \mathrm{A} 645 \times \mathrm{V} /(1000 \times \mathrm{W})} \\
& {[\mathrm{Chl} \mathrm{b}]=22.9 \times \mathrm{A} 645-4.68 \times \mathrm{A} 663 \times \mathrm{V} /(1000 \times \mathrm{W})} \\
& {[\mathrm{Chl} \mathrm{a}+\mathrm{b}]=20.2 \times \mathrm{A} 645+8.02 \times \mathrm{A} 663 \times \mathrm{V} /(1000 \times \mathrm{W})}
\end{aligned}
$$

All experiments were repeated three times. 


\section{Root Elongation Assay}

After germination, sterilized seeds were sown on filter paper moistened with $0.1 \mathrm{mM} \mathrm{CaCl} 2$. Before treatment with $\mathrm{NaCl}$, the primary root lengths of 3-day-old seedlings were measured and recorded as $\mathrm{L}_{\mathrm{C} 0}$ and $\mathrm{L}_{\mathrm{T} 0}$. After treatment with $\mathrm{NaCl}(0,100,150 \mathrm{mM})$ for 3 days, the primary root lengths were recorded as $\mathrm{L}_{\mathrm{C} 3}$ and $\mathrm{L}_{\mathrm{T} 3}$. Root relative elongation rates were calculated using the formula previously reported by Pan et al. (2004):

$$
\operatorname{RER}(\%)=\left(\mathrm{L}_{\mathrm{T} 3}-\mathrm{L}_{\mathrm{T} 0}\right) /\left(\mathrm{L}_{\mathrm{C} 3}-\mathrm{L}_{\mathrm{C} 0}\right) \times 100 \%
$$

\section{Evans Blue Staining}

The cell viability of primary root was evaluated using Evans Blue staining. After treatment with 0 or $150 \mathrm{mM}$ $\mathrm{NaCl}$ for 3 days, 6-day-old seedlings were stained with 2.5\% Evans Blue for $10 \mathrm{~min}$ and then washed twice with deionized water. Prior to observation, the seedlings were soaked in transparent agent for $12 \mathrm{~h}$.

\section{DNA Ladder Analysis}

After $8 \mathrm{~h}$ of treatment with $300 \mathrm{mMNaCl}$, the roots tips of the rice seedlings were collected and ground in liquid nitrogen. DNA was isolated using the CTAB method and then digested with $100 \mathrm{~g} / \mathrm{mL}$ DNase-free RNase for $1 \mathrm{~h}$ at $37^{\circ} \mathrm{C}$ to eliminate RNA contamination. For each sample, an aliquot of DNA $(20 \mu \mathrm{g})$ was separated using a $2 \%(\mathrm{w} / \mathrm{v})$ agarose gel, stained with $0.1 \mu \mathrm{g} / \mathrm{mL}$ ethidium bromide in TE buffer (10 mMTris- $\mathrm{HCl}, \mathrm{pH} 8.0 ; 0.5 \mathrm{mM}$ EDTA) and washed once with TE buffer. The fragmented DNA was observed under UV light using a photostation (UVI, Cambridge, UK).

\section{BCECF and Trypan Blue Staining}

Protoplasts were incubated with $10 \mu \mathrm{M}$ BCECF-AM (Molecular Probes, USA) for $2 \mathrm{~h}$ at $25{ }^{\circ} \mathrm{C}$ in the dark and then treated with $100 \mathrm{mM} \mathrm{NaCl}$ for $3 \mathrm{~h}$. Prior to observation, protoplasts were washed twice with W5 solution and stained with $0.04 \%$ Trypan Blue for $3 \mathrm{~min}$. BCECF signal was visualized with excitation at 465-495 nm and emission at $515-555 \mathrm{~nm}$ using a band pass filter based on a previous method (Tang et al. 2012).

\section{Leaf Water Loss Assay}

Plants germinated under normal growth conditions for 4 weeks. The leaves were detached from various lines with same age and position, and weighed immediately as the initial fresh weight. They were then placed in clean filter papers, and incubated at $25{ }^{\circ} \mathrm{C}$. The decreases in fresh weight were recorded at every $20 \min$ for $5 \mathrm{~h}$. Water loss was presented as percentage of fresh weight loss versus the initial fresh weight (Zhang et al. 2012).

\section{Stomata Observation}

The dental resin impression method was used with nail polish as an impression material (Kagan et al. 1992; Geisler et al. 2000). Impressions were observed on glass slides using a Zeiss LSM710 NLO two-photon microscope (Mannheim, Germany).

\section{Additional files}

Additional file 1: Supporting information. Table S1. List of primers used in this study ( $F$, forward primer; $R$, reverse primer; $q$, quantitative real-time $P(R)$. Figure $\mathbf{S 1 . T h e ~ g r a i n ~ w i d t h ~ a n d ~ 1 0 0 0 - g r i a n ~ w e i g h t ~ o f ~ t h e ~}$ WT, over-expression lines and RNAi line.Values are means, and error bars represent the SD from three independent experiments. Asterisks indicate a significant difference between WT and transgenic lines (t-test; ${ }^{* *}$, $P<0.01$ ). Figure S2.The percentages of water loss of detached leaves from WT and transgenic lines.Values are means, and error bars represent the SD from three independent experiments. (DOCX $825 \mathrm{~kb}$ )

\section{Abbreviations}

BCECF-AM: 2',7'-bis-(2-carboxyethyl)-5-(and-6)-carboxyfluoresceinacetoxymethyl; BCL-2: B-cell lymphoma-2; GFP: Green fluorescent protein; MPK6: Mitogen-activated protein kinase 6; PCD: Programmed cell death; qRT-PCR: Real time quantitative polymerase chain reaction; ROS: Reactive oxygen species; SOS: Salt-overly-sensitive; VPE: Vacuolar processing enzymes

\section{Acknowledgements}

This study was supported by the National Natural Science Foundation of China (Grant number 31171615) and the Natural Science Foundation of Zhejiang Province (Y15C130004).

\section{Competing interests}

The authors declare that they have no competing interests.

\section{Authors' contributions}

LW, DM, ZM and BH contributed to the experimental design. LW, DM, GF, WM, ZZ and BH contributed to experiment performance, data analysis and drafted the manuscript. HN and YY contributed to good advice of designing experiment. All authors read and approved the final manuscript.

\section{Author details}

${ }^{1}$ Institute of Genetics and Regenerative Biology, Key Laboratory for Cell and Gene Engineering of Zhejiang Province, College of Life Sciences, Zhejiang University, Hangzhou, China. ${ }^{2}$ State Key Laboratory Breeding Base for Zhejiang Sustainable Pest and Disease Control, Institute of Virology and Biotechnology, Zhejiang Academy of Agricultural Sciences, Hangzhou, China. ${ }^{3}$ Department of Plant Pathology and Huck Institute of Life Sciences, Pennsylvania State University, University Park, PA 16802, USA.

Received: 27 July 2016 Accepted: 21 November 2016 Published online: 29 November 2016

\footnotetext{
References

Albertini A, Simeoni F, Galbiati M, Bauer H, Tonelli C, Cominelli E (2014) Involvement of the vacuolar processing enzyme gamma VPE in response of Arabidopsis thaliana to water stress. Biol Plantarum 58:531-538 Assmann SM (1993) Signal-Transduction in Guard-Cells. Annu Rev Cell Biol 9:345-375 Azeez A, Sane AP, Bhatnagar D, Nath P (2007) Enhanced expression of serine proteases during floral senescence in Gladiolus. Phytochemistry 68:1352-1357

Bai Y, Han N, Wu J, Yang Y, Wang J, Zhu M, Bian H (2014) A transient gene expression system using barley protoplasts to evaluate microRNAs for post-transcriptional regulation of their target genes. Plant Cell Tissue Organ Cult 119:211-219

Balcerowicz M, Hoecker U (2014) Auxin - a novel regulator of stomata differentiation. Trends Plant Sci 19:747-749

Boller T, Wiemken A (1986) Dynamics of Vacuolar Compartmentation. Annu Rev Plant Phys 37:137-164
} 
De Pinto MC, Locato V, De Gara L (2012) Redox regulation in plant programmed cell death. Plant, Cell Environ 35:234-244

Deng MJ, Bian HW, Xie YK, Kim Y, Wang WZ, Lin EP, Zeng ZH, Guo F, Pan JW, Han N, Wang JH, Qian Q, Zhu MY (2011) Bcl-2 suppresses hydrogen peroxide-induced programmed cell death via OsVPE2 and OsVPE3, but not via OSVPE1 and OsVPE4, in rice. Febs Journal 278:4797-4810

Dionisio-Sese ML, Tobita S (1998) Antioxidant responses of rice seedlings to salinity stress. Plant Sci 135:1-9

Gao JP, Chao DY, Lin HX (2007) Understanding abiotic stress tolerance mechanisms: Recent studies on stress response in rice. J Integr Plant Biol 49:742-750

Gechev TS, Van Breusegem F, Stone JM, Denev I, Laloi C (2006) Reactive oxygen species as signals that modulate plant stress responses and programmed cell death. Bioessays 28:1091-1101

Geisler M, Nadeau J, Sack FD (2000) Oriented asymmetric divisions that generate the stomatal spacing pattern in Arabidopsis are disrupted by the too many mouths mutation. Plant Cell 12:2075-2086

Hara-Nishimura I, Hatsugai N (2011) The role of vacuole in plant cell death. Cell Death Differ 18:1298-1304

Haranishimura I, Inoue K, Nishimura M (1991) A Unique Vacuolar Processing Enzyme Responsible for Conversion of Several Proprotein Precursors into the Mature Forms. FEBS Lett 294:89-93

Haranishimura I, Takeuchi Y, Nishimura M (1993) Molecular Characterization of a Vacuolar Processing Enzyme Related to a Putative Cysteine Proteinase of Schistosoma-Mansoni. Plant Cell 5:1651-1659

Hara-Nishimura I, Kinoshita T, Hiraiwa N, Nishimura M (1998) Vacuolar processing enzymes in protein-storage vacuoles and lytic vacuoles. J Plant Physiol 152:668-674

Hara-Nishimura I, Hatsugai N, Nakaune S, Kuroyanagi M, Nishimura M (2005) Vacuolar processing enzyme: an executor of plant cell death. Curr Opin Plant Biol 8:404-408

Hatsugai N, Kuroyanagi M, Yamada K, Meshi T, Hara-Nishimura I, Nishimura M (2004a) Vacuolar processing enzyme exhibiting caspase-1-like activity is involved in TMV-induced hypersensitive cell death in tobacco. Plant and Cell Physiology 45, S143-S143

Hatsugai N, Kuroyanagi M, Yamada K, Meshi T, Tsuda S, Kondo M, Nishimura M, Hara-Nishimura I (2004b) A plant vacuolar protease, VPE, mediates virus-induced hypersensitive cell death. Science 305, 855-858

Hatsugai N, Kuroyanagi M, Nishimura M, Hara-Nishimura I (2006) A cellular suicide strategy of plants: vacuole-mediated cell death. Apoptosis 11:905-911

Hatsugai N, Yamada K, Yamada S, Hara-Nishimura I (2015) Vacuolar processing enzyme in plant programmed cell death. Front Plant Sci 6:234

Higaki T, Kurusu T, Hasezawa S, Kuchitsu K (2011) Dynamic intracellular reorganization of cytoskeletons and the vacuole in defense responses and hypersensitive cell death in plants. J Plant Res 124:315-324

Hiraiwa N, Takeuchi Y, Nishimura M, Haranishimura I (1993) A Vacuolar Processing Enzyme in Maturing and Germinating-Seeds - Its Distribution and Associated Changes during Development. Plant Cell Physiol 34:1197-1204

Horie T, Karahara I, Katsuhara M (2012) Salinity tolerance mechanisms in glycophytes: An overview with the central focus on rice plant. Rice 5:11

Huh GH, Damsz B, Matsumoto TK, Reddy MP, Rus AM, Ibeas Jl, Narasimhan ML, Bressan RA, Hasegawa PM (2002) Salt causes ion disequilibrium-induced programmed cell death in yeast and plants. Plant J 29:649-659

Jiang AL, Cheng YW, Li JY, Zhang W (2008) A zinc-dependent nuclear endonuclease is responsible for DNA laddering during salt-induced programmed cell death in root tip cells of rice. J Plant Physiol 165:1134-1141

Kagan ML, Novoplansky N, Sachs T (1992) Variable Cell Lineages Form the Functional Pea Epidermis. Ann Bot 69:303-312

Kariya K, Demiral T, Sasaki T, Tsuchiya Y, Turkan I, Sano T, Hasezawa S, Yamamoto Y (2013) A novel mechanism of aluminium-induced cell death involving vacuolar processing enzyme and vacuolar collapse in tobacco cell line BY-2. J Inorg Biochem 128:196-201

Khatun S, Flowers TJ (1995) Effects of Salinity on Seed Set in Rice. Plant, Cell Environ 18:61-67

Kim C, Meskauskiene R, Zhang S, Lee KP, Lakshmanan Ashok M, Blajecka K, Herrfurth C, Feussner I, Apel K (2012) Chloroplasts of Arabidopsis are the source and a primary target of a plant-specific programmed cell death signaling pathway. Plant Cell 24:3026-3039

Kim YH, Wang MQ, Bai Y, Zeng ZH, Guo F, Han N, Bian HW, Wang JH, Pan JW Zhu MY (2014) Bcl-2 suppresses activation of VPEs by inhibiting cytosolic $\mathrm{Ca} 2+$ level with elevated $\mathrm{K}+$ efflux in $\mathrm{NaCl}$-induced PCD in rice. Plant Physiol Bioch 80:168-175
Kinoshita T, Yamada K, Hiraiwa N, Kondo M, Nishimura M, Hara-Nishimura I (1999) Vacuolar processing enzyme is up-regulated in the lytic vacuoles of vegetative tissues during senescence and under various stressed conditions. Plant J 19:43-53

Krishnan HB, Okita TW (1986) Structural Relationship among the Rice Glutelin Polypeptides. Plant Physiol 81:748-753

Kudla J, Batistic O, Hashimoto K (2010) Calcium Signals: The Lead Currency of Plant Information Processing. Plant Cell 22:541-563

Kuroyanagi M, Yamada K, Hatsugai N, Kondo M, Nishimura M, Hara-Nishimura I (2005) Vacuolar processing enzyme is essential for mycotoxin-induced cell death in Arabidopsis thaliana. J Biol Chem 280:32914-32920

Lam E (2004) Controlled cell death, plant survival and development. Nat Rev Mol Cell Bio 5:305-315

Li JY, Jiang AL, Zhang W (2007) Salt stress-induced programmed cell death in rice root tip cells. J Integr Plant Biol 49:481-486

Li Z, Yue HY, Xing D (2012) MAP Kinase 6-mediated activation of vacuolar processing enzyme modulates heat shock-induced programmed cell death in Arabidopsis. New Phytol 195:85-96

Lin JS, Wang Y, Wang GX (2006) Salt stress-induced programmed cell death in tobacco protoplasts is mediated by reactive oxygen species and mitochondrial permeability transition pore status. J Plant Physiol 163:731-739

Liu T, Ohashi-Ito K, Bergmann DC (2009) Orthologs of Arabidopsis thaliana stomatal bHLH genes and regulation of stomatal development in grasses. Development 136:2265-2276

Menezes-Benavente L, Teixeira FK, Kamei CLA, Margis-Pinheiro M (2004) Salt stress induces altered expression of genes encoding antioxidant enzymes in seedlings of a Brazilian indica rice (Oryza sativa L.). Plant Sci 166:323-331

Mino M, Murata N, Date S, Inoue M (2006) Collapse of vacuole is a direct factor of cell death in the seedling of interspecific hybrid of Nicotiana gossei $x$ N-tabacum. Plant Cell Physiol 47:S182-S182

Mittler R, Simon L, Lam E (1997) Pathogen-induced programmed cell death in tobacco. J Cell Sci 110:1333-1344

Neuhaus JM, Sticher L, Meins F, Boller T (1991) A Short C-Terminal Sequence Is Necessary and Sufficient for the Targeting of Chitinases to the Plant Vacuole. Proc Natl Acad Sci U S A 88:10362-10366

Nicholson DW (1999) Caspase structure, proteolytic substrates, and functionduring apoptotic cell death. Cell Death Differ 6:1028-1042

Obara K, Kuriyama H, Fukuda H (2001) Direct evidence of active and rapid nuclear degradation triggered by vacuole rupture during programmed cell death in Zinnia. Plant Physiol 125:615-626

Pan JW, Ye D, Wang LL, Hua J, Zhao GF, Pan WH, Han N, Zhu MY (2004) Root border cell development is a temperature-insensitive and Al-sensitive process in barley. Plant Cell Physiol 45, 751-760.

Rea PA, Sanders D (1987) Tonoplast Energization - 2 H+ Pumps, One Membrane. Physiol Plantarum 71:131-141

Rojo E, Zouhar J, Carter C, Kovaleva V, Raikhel NV (2003) A unique mechanism for protein processing and degradation in Arabidopsis thaliana. Proc Natl Acad Sci U S A 100:7389-7394

Sahi C, Singh A, Kumar K, Blumwald E, Grover A (2006) Salt stress response in rice: genetics, molecular biology, and comparative genomics. Funct Integr Genomics 6:263-284

Samuilov VD, Lagunova EM, Gostimsky SA, Timofeev KN, Gusev MV (2003) Role of chloroplast photosystems II and I in appoptosis of pea guard cells. Biochemistry-Moscow 68:912-917

Serrano R, Rodriguez-Navarro A (2001) lon homeostasis during salt stress in plants. Curr Opin Cell Biol 13:399-404

Shabala S (2009) Salinity and programmed cell death: unravelling mechanisms for ion specific signalling. J Exp Bot 60:709-711

Swanson SJ, Jones RL (1996) Gibberellic acid induces vacuolar acidification in barley aleurone. Plant Cell 8:2211-2221

Takemoto Y, Coughlan SJ, Okita TW, Satoh H, Ogawa M, Kumamaru T (2002) The Rice Mutant esp2 Greatly Accumulates the Glutelin Precursor and Deletes the Protein Disulfide Isomerase. Plant Physiology 128(4):1212-1222.

Tamura K, Shimada T, Ono E, Tanaka Y, Nagatani A, Higashi S, Watanabe M, Nishimura M, Hara-Nishimura I (2003) Why green fluorescent fusion proteins have not been observed in the vacuoles of higher plants. Plant J 35:545-555

Tang RJ, Liu H, Yang Y, Yang L, Gao XS, Garcia VJ, Luan S, Zhang HX (2012) Tonoplast calcium sensors CBL2 and CBL3 control plant growth and ion homeostasis through regulating V-ATPase activity in Arabidopsis. Cell Res 22:1650-1665 
van Doorn WG (2011) Classes of programmed cell death in plants, compared to those in animals. J Exp Bot 62:4749-4761

Wang YH, Zhu SS, Liu SJ, Jiang L, Chen LM, Ren YL, Han XH, Liu F, Ji SL, Liu X, Wan JM (2009) The vacuolar processing enzyme OSVPE1 is required for efficient glutelin processing in rice. Plant J 58:606-617

Williams B, Dickman M (2008) Plant programmed cell death: can't live with it: can't live without it. Mol Plant Pathol 9:531-544

Wituszynska W, Szechynska-Hebda M, Sobczak M, Rusaczonek A, KozlowskaMakulska A, Witon D, Karpinski S (2015) LESION SIMULATING DISEASE 1 and ENHANCED DISEASE SUSCEPTIBILITY 1 differentially regulate UV-C-induced photooxidative stress signalling and programmed cell death in Arabidopsis thaliana. Plant, Cell Environ 38:315-330

Yamada K, Matsushima R, Nishimura M, Hara-Nishimura I (2001) A slow maturation of a cysteine protease with a granulin domain in the vacuoles of senescing arabidopsis leaves. Plant Physiol 127:1626-1634

Yamagata H, Sugimoto T, Tanaka K, Kasai Z (1982) Biosynthesis of Storage Proteins in Developing Rice Seeds. Plant Physiol 70:1094-1100

Yoshida S, Forno D, Cock J, Gomez K (1976) Laboratory Manual for Physiological Studies of Rice, 3rd edn. International Rice Research Institute, Manila, Philippines

Yu XJ, Li GX, Xu D, Dong XL, Qi XX, Deng YQ (2006) An improvement of cucumber cotyledon greening bioassay for cytokinins. Acta Physiol Plant 28:9-11

Zhang KW, Xia XY, Zhang YY, Gan SS (2012) An ABA-regulated and Golgi-localized protein phosphatase controls water loss during leaf senescence in Arabidopsis. Plant J 69:667-678

Zhang HY, Niu XL, Liu J, Xiao FM, Cao SQ, Liu YS (2013a) RNAi-Directed Downregulation of Vacuolar H+-ATPase Subunit A Results in Enhanced Stomatal Aperture and Density in Rice. PloS one 8 (7) e69046

Zhang J, Li QF, Huang WW, Xu XY, Zhang XL, Hui MX, Zhang MK, Zhang LG (2013b) A Vacuolar Processing Enzyme RsVPE1 Gene of Radish Is Involved in Floral Bud Abortion under Heat Stress. International journal of molecular sciences 14, 13346-13359

Zhu JK (2001) Plant salt tolerance. Trends Plant Sci 6:66-71

Zhu JK (2003) Regulation of ion homeostasis under salt stress. Curr Opin Plant Biol 6:441-445

\section{Submit your manuscript to a SpringerOpen ${ }^{\circ}$ journal and benefit from:}

- Convenient online submission

- Rigorous peer review

- Immediate publication on acceptance

- Open access: articles freely available online

High visibility within the field

Retaining the copyright to your article 